\title{
IMPACT OF AGRICULTURAL CHEMICALS ON SELECTED HEAVY METALS ACCUMULATION IN HERB PLANTS
}

\author{
MALINOWSKA, E. ${ }^{*}$ JANKOWSKI, K. \\ Department of Grassland and Green Areas Creation, Siedlce University of Natural Sciences \\ and Humanities, Prusa 14 Street, 08-110 Siedlce, Poland \\ (phone: +48-25-643-13-19) \\ *Coressponding author \\ e-mail: malinowskae@uph.edu.pl \\ (Received $25^{\text {th }}$ Nov 2015; accepted $3^{\text {rd }}$ May 2016)
}

\begin{abstract}
The aim of this paper is to determine cadmium, lead and nickel concentration in different herb plants and in the soil collected in the areas close to winter wheat and grain maize fields. The following herbs were analyzed: Achillea millefolium, Cichorium intybus L., Equisetum arvense, Polygonum persicaria, Plantago lanceolata L., and Plantago major L.. They were sampled one and ten meters away from the edge of the fields. The plants, 70 of each species, were collected during the flowering stage from 1 to 20 July 2014. At the same places soil samples were taken. Cadmium, lead and nickel concentration was determined with inductively coupled plasma-atomic emission spectrometry. All the herbs growing near the wheat field, except for Cichorium intybus L., had lead concentration above the limit. For other metals the concentration was below the limits set for dried herbs. Herbs plants growing close to the wheat field had a higher concentration of heavy metals than the same plants growing near the grain maize field. The average concentration of cadmium, lead and nickel in the soil around the fields was much lower than the concentration of the same metals in average, non-contaminated soil. In the soil-plant system the highest accumulation coefficient of heavy metals was for cadmium, then for nickel while the lowest was for lead.
\end{abstract}

Keywords: cadmium, lead, nickel, herbs, soil

\section{Introduction}

Heavy metals are among the most harmful environmental pollutants and because of that many publications are devoted to their effects on plants and soil in the areas close to main roads and motorways (Van Bohemen and Van de Laak, 2003; Plesničar and Zupančič, 2005; Jankowski et al., 2015; Malinowska et al., 2015). Yet, not much research has been done to study soil and plant contamination around agricultural fields. Due to the fact that the use of agricultural chemicals is growing, such places are exposed to more and more pollutants. Herbs growing in the natural habitat around farm fields are often used for medical purposes and that is why the accumulation of heavy metals and other pollutants in those plants should be monitored so that they will not pile up in living organisms (Sembratowicz et al., 2009; Ulewicz-Magulska et al., 2009; Luginina and Egoshina, 2013). Not only heavy metals but also pesticide residues in herbs growing in the wild should be monitored because in Europe such plants are used to treat many health conditions (Deng et al., 2004; Gracia-Rico et al., 2007; Arslan et al., 2010).

The aim of this paper is to determine cadmium, lead and nickel concentration in different herb plants, in the aspect of their medicinal use, and in the soil around cultivated fields of wheat and grain maize. 


\section{Materials and methods}

The research material included the following species sampled both one and ten meters away from the edges of a winter wheat field and grain maize field: Achillea millefolium L., Cichorium intybus L., Equisetum arvense L., Polygonum persicaria L., Plantago lanceolata L. and Plantago major L. The plant material originated from farms located in the Siedlce County, in the east-central part of Poland. The fields were located far away from main roads and were not affected by dust emission. According to recommendations, both mineral and organic fertilizers but also plant protection products were used for growing the crops. The plants, 70 samples of each species, were gathered during the flowering stage from 1 to 20 July 2014. At the same places, from the root zone, soil samples were also collected. Crops growing in the fields were not tested for heavy metals because that will be the subject of further studies.

The plants: leaves, stalks and inflorescence, were dried at the temperature of $105^{\circ} \mathrm{C}$. Next the plant material was ground to particles of $0.25 \mathrm{~mm}$ in diameter and $1 \mathrm{~g}$ of it was weighed and put into a porcelain crucible. Then the crucible was placed in a muffle furnace for 15 hours to oxidize organic matter at the temperature of $450{ }^{\circ} \mathrm{C}$. Next $10 \mathrm{ml}$ of hydrochloric acid solution (1:1) was added and the mixture was put into a sand bath to evaporate, to decompose carbonates and to remove silica. After adding $5 \mathrm{ml}$ of $10 \%$ hydrochloric acid solution, the contents of the crucible were filtered through a hard filter into a $100 \mathrm{ml}$ volumetric flask and water was added up to the mark. Lead, cadmium and nickel concentration was determined using inductively coupled plasma atomic emission spectrometry (ICP-AES). Soil $\mathrm{pH}$, the value of which ranged from 5.05 to 6.30, was measured with the potentiometric method.

All of the data were statistically analyzed and differences between means were assessed using analysis of variance with the Statistica software, Version 10.0 StatSoft, applied. Tukey's test was used to determine $\mathrm{LSD}_{0.05}$ for means that were significantly different (StatSoft, Inc. 2011). The intensity of lead, cadmium and nickel accumulation in the herbs was measured by means of the accumulation coefficient (AC), using the formula (Wesołowski and Radecka, 2003) $\mathrm{AC}=\mathrm{c}_{\mathrm{p}} / \mathrm{c}_{\mathrm{s}}\left(\mathrm{c}_{\mathrm{p}}-\right.$ content of the metal in the plant, $\mathrm{c}_{\mathrm{s}}-$ content of the metal in the soil):

$$
\begin{array}{ll}
\text { AC }<0,01 & \text { - no accumulation; } \\
\text { AC }<0,1 & \text { - slight accumulation; } \\
\text { AC }-1 & \text { - medium accumulation; } \\
\text { AC }>1 & \text { - high accumulation. }
\end{array}
$$

Additionally, correlation coefficient values between the content of lead, cadmium and nickel in the soil and the content of the same metals in the plants growing there were calculated.

\section{Results and discussion}

Cadmium concentration in the plants was significantly related to the herb species and to the distance from the farming fields (Table 1). The highest average amount of this metal was found in Polygonum persicaria plants sampled close to both winter wheat and grain maize fields: 0.256 and $0.220 \mathrm{mg} \mathrm{kg}^{-1}$, respectively. In herbs growing close to the winter wheat field the lowest amount of cadmium was found in Equisetum arvense $\left(0.165 \mathrm{mg} \mathrm{kg}^{-1}\right)$, while in the area of the grain maize field the lowest cadmium concentration was in Plantago major $\left(0.122 \mathrm{mgkg}^{-1}\right)$. This concentration was 
significantly higher in herb plants collected at the distance of one meter from the fields than in those growing ten meters from the field. Like in the case of cadmium, there was a relationship between the amount of lead and the herb species as well as between the concentration of this metal and the place from which the plant was collected. Thus, the average lead concentration was two times higher in herbs growing close to the winter field than in those sampled close to the grain maize field. It might have been caused by the fact that wheat was treated with agricultural chemicals more often than maize. The highest average concentration of lead (3.01 mg kg $\mathrm{g}^{-1}$ ) was found in Equisetum arvense growing near the winter wheat field, while in plants sampled around the maize field the highest concentration of lead was in Plantago major L. $\left(1.29 \mathrm{mg} \mathrm{kg}^{-1}\right)$. According to Regulation of the Minister of Health (2003), lead concentration in herbs and in dry herbs used in cooking should not exceed $2 \mathrm{mg} \mathrm{kg}^{-1} \mathrm{DM}$ while in the case of cadmium this concentration should not be higher than $0.3 \mathrm{mg} \mathrm{kg}^{-1} \mathrm{DM}$. The amount of cadmium did not exceed the limits but lead concentration was too high in all herb plants growing close to the wheat field, with the exception of Cichorium intybus L.

Table 1. Average heavy metal concentration $\left(\mathrm{mg} \mathrm{kg}^{-1}\right)$ in selected herb species growing around winter wheat and grain maize fields

\begin{tabular}{|c|c|c|c|c|c|c|c|c|c|}
\hline \multirow[b]{2}{*}{ Species } & \multicolumn{3}{|c|}{ Cd } & \multicolumn{3}{|c|}{$\mathbf{P b}$} & \multicolumn{3}{|c|}{$\mathbf{N i}$} \\
\hline & $1 \mathrm{~m}$ & $10 \mathrm{~m}$ & mean & $1 \mathrm{~m}$ & $\begin{array}{l}10 \\
\mathrm{~m}\end{array}$ & mean & $1 \mathrm{~m}$ & $10 \mathrm{~m}$ & Mean \\
\hline \multicolumn{10}{|c|}{ Winter wheat field } \\
\hline Achillea millefolium & 0.251 & 0.150 & 0.201 & 2.05 & 1.99 & 2.02 & 0.850 & 0.901 & 0.875 \\
\hline Cichorium intybus $\mathrm{L}$. & 0.290 & 0.200 & 0.245 & 1.57 & 1.43 & 1.50 & 1.00 & 1.75 & 1.38 \\
\hline Polygonum persicaria & 0.320 & 0.192 & 0.256 & 2.09 & 2.00 & 2.05 & 1.81 & 1.25 & 1.53 \\
\hline Plantago lanceolata $\mathrm{L}$. & 0.190 & 0.170 & 0.185 & 2.81 & 2.45 & 2.63 & 1.05 & 1.39 & 1.22 \\
\hline Plantago major $\mathrm{L}$. & 0.171 & 0.181 & 0.176 & 2.67 & 2.05 & 2.36 & 1.20 & 1.35 & 1.28 \\
\hline Equisetum arvense & 0.200 & 0.130 & 0.165 & 3.05 & 2.96 & 3.01 & 0.980 & 1.05 & 1.02 \\
\hline mean & 0.237 & 0.171 & 0.205 & 2.37 & 2.15 & 2.26 & 1.15 & 1.28 & 1.22 \\
\hline $\mathrm{LSD}_{0.05}$ for: A-species & & 0.068 & & & 0.266 & & & 0.167 & \\
\hline B-distance & & 0.026 & & & 0.103 & & & 0.064 & \\
\hline $\mathrm{A} / \mathrm{B}$ - interaction & & 0.097 & & & 0.377 & & & 0.237 & \\
\hline B/A -interaction & & 0.065 & & & 0.251 & & & 0.158 & \\
\hline \multicolumn{10}{|c|}{ Grain maize field } \\
\hline Achillea millefolium & 0.220 & 0.190 & 0.205 & 1.02 & 1.24 & 1.13 & 0.901 & 1.05 & 0.975 \\
\hline Cichorium intybus $\mathbf{L}$. & 0.171 & 0.161 & 0.165 & 1.23 & 1.12 & 1.18 & 1.10 & 0.891 & 0.996 \\
\hline Polygonum persicaria & 0.252 & 0.190 & 0.220 & 0.998 & 1.02 & 1.01 & 0.95 & 1.14 & 1.05 \\
\hline Plantago lanceolata $\mathrm{L}$. & 0.190 & 0.111 & 0.147 & 1.03 & 1.09 & 1.06 & 1.03 & 1.18 & 1.11 \\
\hline Plantago major $\mathbf{L}$. & 0.140 & 0.101 & 0.122 & 1.24 & 1.34 & 1.29 & 1.21 & 1.02 & 1.11 \\
\hline Equisetum arvense & 0.190 & 0.140 & 0.163 & 0.988 & 1.17 & 1.08 & 0.850 & 0.980 & 0.915 \\
\hline mean & 0.193 & 0.147 & 0.170 & 1.09 & 1.16 & 1.12 & 1.01 & 1.04 & 1.03 \\
\hline $\mathrm{LSD}_{0.05}$ for: A-species & & 0.035 & & & 0.109 & & & 0.181 & \\
\hline B-distance & & 0.014 & & & 0.042 & & & n.s. & \\
\hline $\mathrm{A} / \mathrm{B}$ - interaction & & 0.050 & & & 0.154 & & & 0.256 & \\
\hline $\mathrm{B} / \mathrm{A}$-interaction & & 0.033 & & & 0.103 & & & 0.171 & \\
\hline
\end{tabular}

n.s.- not significant difference, confidence interval $\mathrm{p} \leq 0.05$

Nickel accumulation was significantly affected by the plant species only. On average the highest concentration of this metal was in Polygonum persicaria, while the lowest 
was in Equisetum arvense and Achillea millefolium growing close to both wheat and maize fields. The concentration of nickel in all herb plants ranged from 0.850 to 1.81 $\mathrm{mg} \mathrm{kg}^{-1} \mathrm{DM}$. Contrary to those results, Wiechuła et al. (2012) found a few times higher concentration of nickel in Utrica dioica L. growing in woods in the Lower Silesia Voivodeship. According to Błoniarz et al. (2008) average nickel concentration in plants usually ranges from 0.1 to $5.0 \mathrm{mg} \mathrm{kg}^{-1} \mathrm{DM}$. In another publication Başgel and Erdemoğlu (2006) say that nickel concentration in Utrica dioica L. stands at $3.6 \mathrm{mg} \mathrm{kg}{ }^{-}$ ${ }^{1} \mathrm{DM}$. The differences in the amount of heavy metals in plants can be explained by differences in the mobility of the metal and in the soil $\mathrm{pH}$ but this amount also varies in different plant species and in different plant parts (Barazani et al., 2004; Ražic et al., 2008; Salahinejad and Aflaki, 2010).

The highest concentration of cadmium $\left(0.238 \mathrm{mg} \mathrm{kg}^{-1} \mathrm{DM}\right)$ and nickel $\left(1.29 \mathrm{mg} \mathrm{kg}^{-}\right.$ $\left.{ }^{1} \mathrm{DM}\right)$ was found in the biomass of Polygonum persicaria, and the highest concentration of lead (2.04 mg kg-1 DM) was in Equisetum arvense (Table 2). The average concentration of all the metals in the experiment did not exceed natural concentration of those metals in plants, which means that the latter can be used in medicine. Average concentration is not always a good indicator and should be used together with other ways of controlling accumulation of heavy metals to reduce their harmful effects on living organisms. In Plantago lanceolate, Plantago major and Equisetum arvense lead concentration was exceeded by $50 \%$ and in Polygonum persicaria by $25 \%$ (Regulation of the Minister of Health, 2003). Considering heavy metals, the average highest coefficient of variation was for cadmium (13.20\%), and the lowest for nickel $\mathrm{Ni}$ $(6.34 \%)$. Thus, the monitoring should be detailed, among other things taking into account the plant species and its distance from agricultural fields.

Table 2. Heavy metal concentration ( $\mathrm{mg}^{\mathrm{kg}} \mathrm{g}^{-1} \mathrm{~s} . \mathrm{m}$.) in selected plant species growing close to farming fields

\begin{tabular}{|c|c|c|c|c|c|c|c|c|c|c|c|c|}
\hline \multirow[b]{2}{*}{ Species } & \multicolumn{4}{|c|}{ Cd } & \multicolumn{4}{|c|}{$\mathbf{P b}$} & \multicolumn{4}{|c|}{$\mathbf{N i}$} \\
\hline & Mean & Min & $\operatorname{Max}$ & $\begin{array}{c}\mathrm{V} \\
(\%)\end{array}$ & Mean & Min & Max & $\begin{array}{c}\mathrm{V} \\
(\%)\end{array}$ & Mean & Min & $\operatorname{Max}$ & $\begin{array}{c}\mathrm{V} \\
(\%)\end{array}$ \\
\hline $\begin{array}{l}\text { Achillea } \\
\text { millefolium }\end{array}$ & 0.203 & 0.178 & 0.254 & 5.42 & 1.58 & 1.23 & 2.15 & 16.27 & 0.925 & 0.874 & 1.09 & 3.46 \\
\hline $\begin{array}{l}\text { Cichorium } \\
\text { intybus } \mathrm{L} .\end{array}$ & 0.206 & 0.185 & 0.296 & 5.83 & 1.34 & 1.03 & 1.78 & 15.60 & 1.19 & 1.01 & 1.85 & 10.59 \\
\hline $\begin{array}{l}\text { Polygonum } \\
\text { persicaria }\end{array}$ & 0.238 & 0.201 & 0.328 & 6.73 & 1.53 & 1.03 & 2.56 & 19.22 & 1.29 & 1.10 & 1.98 & 9.22 \\
\hline $\begin{array}{l}\text { Plantago } \\
\text { lanceolata } \mathbf{L} .\end{array}$ & 0.166 & 0.116 & 0.210 & 18.67 & 1.71 & 1.55 & 2.99 & 8.30 & 0.775 & 0.712 & 1.49 & 2.97 \\
\hline $\begin{array}{l}\text { Plantago } \\
\text { major L. }\end{array}$ & 0.149 & 0.100 & 0.198 & 16.11 & 1.83 & 1.56 & 2.96 & 6.61 & 1.20 & 1.02 & 1.44 & 9.75 \\
\hline $\begin{array}{l}\text { Equisetum } \\
\text { arvense }\end{array}$ & 0.164 & 0.100 & 0.230 & 18.29 & 2.04 & 1.20 & 3.11 & 13.19 & 0.965 & 0.923 & 1.15 & 2.07 \\
\hline mean & 0.188 & 0.147 & 0.252 & 11.84 & 1.67 & 1.27 & 2.59 & 13.20 & 1.06 & 0.940 & 1.50 & 6.34 \\
\hline $\operatorname{LSD}_{0.05}$ & 0.032 & & & & 0.201 & & & & 0.158 & & & \\
\hline
\end{tabular}

V-coefficient of variation, confidence interval $\mathrm{p} \leq 0.05$

Similarly to plants, there was a relationship between soil concentration of the metals and the plant species but also between heavy metal concentration in the soil and the distance of the sampling point from the fields (Table 3). The average cadmium, lead and 
nickel concentration in soil sampled from around the fields was much lower than the corresponding values for non-contaminated soil included by Terelak and Piotrowska (1998) and Kabata-Pendias (1999). Natural cadmium concentration in soil around the world ranges from 0.20 to $1.05 \mathrm{mg} \mathrm{kg}^{-1}$, and is usually not higher that $0.5 \mathrm{mg} \cdot \mathrm{kg}^{-1}$ (Alloway, 1990; Kabata-Pendias and Pendias, 1999). In Poland it varies between 0.03 and $0.22 \mathrm{mg} \mathrm{kg}^{-1}$ (Kabata-Pendias 2000). In turn, natural nickel concentration in Polish soil ranges from 0.1 to $173 \mathrm{mg} \mathrm{kg}^{-1}$ (Terelak et al., 2002). On average heavy metal concentration in the soil around the grain maize field was higher than that concentration in the soil around the winter wheat field. Nickel concentration in the soil sampled one meter from the fields was significantly higher than in the soil sampled ten meters from the fields while for other metals the relationship was more complicated. There was more lead ten meters away from the wheat field than one meter. For the grain maize field it was different, with more of this metal one meter away from the field than ten meters from the field.

Table 3. Heavy metal concentration in soil sampled close to a winter wheat field and grain maize field

\begin{tabular}{|c|c|c|c|c|c|c|c|c|c|}
\hline \multirow{2}{*}{ Species } & \multicolumn{3}{|c|}{$\mathrm{Cd}$} & \multicolumn{3}{|c|}{$\mathrm{Pb}$} & \multicolumn{3}{|c|}{$\mathrm{Ni}$} \\
\hline & $1 \mathrm{~m}$ & $10 \mathrm{~m}$ & mean & $1 \mathrm{~m}$ & $10 \mathrm{~m}$ & mean & $1 \mathrm{~m}$ & $10 \mathrm{~m}$ & Mean \\
\hline \multicolumn{10}{|c|}{ Winter wheat field } \\
\hline Achillea millefolium & 0.089 & 0.087 & 0.088 & 5.32 & 5.87 & 5.60 & 1.32 & 1.01 & 1.16 \\
\hline Cichorium intybus $\mathbf{L}$. & 0.071 & 0.089 & 0.080 & 6.87 & 6.01 & 6.44 & 1.02 & 1.23 & 1.13 \\
\hline Polygonum persicaria & 0.094 & 0.098 & 0.096 & 6.41 & 6.87 & 6.64 & 1.57 & 1.42 & 1.50 \\
\hline Plantago lanceolata $\mathrm{L}$. & 0.089 & 0.074 & 0.082 & 5.87 & 5.21 & 5.54 & 1.41 & 1.02 & 1.22 \\
\hline Plantago major $\mathbf{L}$. & 0.087 & 0.065 & 0.076 & 6.21 & 6.01 & 6.11 & 1.63 & 1.38 & 1.46 \\
\hline Equisetum arvense & 0.084 & 0.057 & 0.070 & 5.01 & 6.14 & 5.58 & 1.56 & 1.27 & 1.42 \\
\hline mean & 0.085 & 0.079 & 0.082 & 5.95 & 6.02 & 5.98 & 1.40 & 1.22 & 1.31 \\
\hline $\mathrm{LSD}_{0.05}$ for: A-species & & 0.009 & & & 0.150 & & & 0.240 & \\
\hline B-distance & & 0.004 & & & 0.058 & & & 0.093 & \\
\hline $\mathrm{A} / \mathrm{B}$ - interaction & & 0.013 & & & 0.212 & & & 0.227 & \\
\hline $\mathrm{B} / \mathrm{A}$-interaction & & 0.009 & & & 0.141 & & & 0.340 & \\
\hline \multicolumn{10}{|c|}{ Grain maize field } \\
\hline Achillea millefolium & 0.074 & 0.090 & 0.082 & 4.41 & 4.78 & 4.59 & 1.05 & 1.21 & 1.13 \\
\hline Cichorium intybus $\mathrm{L}$. & 0.085 & 0.080 & 0.083 & 7.01 & 6.89 & 6.95 & 1.31 & 1.08 & 1.20 \\
\hline Polygonum persicaria & 0.074 & 0.068 & 0.071 & 7.25 & 6.54 & 6.90 & 1.78 & 1.51 & 1.65 \\
\hline Plantago lanceolata $\mathrm{L}$. & 0.102 & 0.089 & 0.096 & 6.33 & 5.36 & 5.85 & 1.58 & 1.31 & 1.45 \\
\hline Plantago major $\mathbf{L}$. & 0.097 & 0.085 & 0.091 & 7.84 & 6.87 & 7.36 & 1.62 & 1.48 & 1.55 \\
\hline Equisetum arvense & 0.111 & 0.087 & 0.099 & 6.58 & 6.01 & 6.30 & 1.41 & 1.09 & 1.25 \\
\hline mean & 0.090 & 0.099 & 0.087 & 6.57 & 6.07 & 6.32 & 1.46 & 1.28 & 1.37 \\
\hline $\mathrm{LSD}_{0.05}$ for: A-species & & 0.013 & & & 0.566 & & & 0.227 & \\
\hline B-distance & & 0.005 & & & 0.218 & & & 0.087 & \\
\hline A/B-interaction & & 0.018 & & & 0.800 & & & 0.214 & \\
\hline B/A-interaction & & 0.012 & & & 0.534 & & & 0.321 & \\
\hline
\end{tabular}

confidence interval $\mathrm{p} \leq 0.05$

In the case of cadmium a higher concentration of this metals was in the sample points one meter from the wheat field and ten meters in the soil around the maize field. It may indicate that some soil processes affect heavy metals mobility and, at the same time, 
their accumulation by plants. Finally, the value of correlation coefficient between metal concentration in the soil and in the plants did not show any considerable relation.

However, there were significantly different values of the coefficient of heavy metal accumulation in herbs (Table 4). The highest accumulation coefficient was for cadmium, then for nickel and the lowest for lead. According to Kloke et al. (1984) and Kabata-Pendias and Pendias (1999) in the plant-soil system each metal has different absorption properties and, at the same time, different accumulation coefficient. According to those publications cadmium has the highest accumulation coefficient (110) while for nickel it is much lower (0.1-1), and for lead it was the lowest (0.01-0.1). For cadmium this coefficient ranged from 1.19 to 4.08 and was much higher in herbs sampled one meter away from the field than ten meters from the field.

Table 4. Cadmium, lead and nickel accumulation coefficient in herb plants

\begin{tabular}{|c|c|c|c|c|c|c|c|c|c|}
\hline \multirow{2}{*}{ Species } & \multicolumn{3}{|c|}{$\mathrm{Cd}$} & \multicolumn{3}{|c|}{$\mathrm{Pb}$} & \multicolumn{3}{|c|}{$\mathrm{Ni}$} \\
\hline & $1 \mathrm{~m}$ & $10 \mathrm{~m}$ & mean & $1 \mathrm{~m}$ & $10 \mathrm{~m}$ & mean & $1 \mathrm{~m}$ & $10 \mathrm{~m}$ & Mean \\
\hline \multicolumn{10}{|c|}{ Winter wheat field } \\
\hline Achillea millefolium & 2.82 & 1.72 & 2.27 & 0.385 & 0.339 & 0.362 & 0.644 & 0.892 & 0.768 \\
\hline Cichoriuı & 4.08 & 2.82 & 3.45 & 0.238 & 0.238 & 0.238 & 0.980 & 1.42 & 1.20 \\
\hline Polygonu & 3.40 & 1.96 & 2.68 & 0.326 & 0.291 & 0.309 & 1.15 & 0.880 & 1.02 \\
\hline Plantag & 2.13 & 2.30 & 2.22 & 0.479 & 0.470 & 0.475 & 0.745 & 1.36 & 1.05 \\
\hline Plant & 1.97 & 2.78 & 2.38 & 0.430 & 0.341 & 0.386 & 0.736 & 0.978 & 0.857 \\
\hline$E q u$ & 2.38 & 2.28 & 2.33 & 0.609 & 0.482 & 0.546 & 0.628 & 0.827 & 0.728 \\
\hline & 2.80 & 2.31 & 2.55 & 0.411 & 0.360 & 0.386 & 0.814 & 1.06 & 0.937 \\
\hline \multicolumn{10}{|c|}{ Grain maize field } \\
\hline & 2.97 & 2.11 & 2.54 & 0.231 & 0.259 & 0.245 & 0.858 & 0.868 & 0.863 \\
\hline Cichori & 2.01 & 2.01 & 2.01 & 0.175 & 0.163 & 0.169 & 0.840 & 0.825 & 0.833 \\
\hline Polygo & 3.41 & 2.79 & 3.10 & 0.138 & 0.156 & 0.147 & 0.534 & 0.755 & 0.645 \\
\hline Plantago lanceolata $\mathrm{L}$. & 1.86 & 1.25 & 1.56 & 0.163 & 0.203 & 0.183 & 0.652 & 0.901 & 0.777 \\
\hline Plant & 1.44 & 1.19 & 1.32 & 0.158 & 0.195 & 0.177 & 0.747 & 0.689 & 0.718 \\
\hline Equiset & 1.71 & 1.61 & 1.66 & 0.150 & 0.195 & 0.173 & 0.603 & 0.899 & 0.751 \\
\hline mean & 2.23 & 1.83 & 2.03 & 0.169 & 0.195 & 0.182 & 0.706 & 0.823 & 0.764 \\
\hline
\end{tabular}

For lead the values of accumulation coefficient in all herb plants was much higher than the limits, up to six times, ranging from 0.138 to 0.609 despite the fact that lead concentration in the soil was low (Table 3). In herbs sampled close to the maize field nickel accumulation coefficient was higher than 1 whereas in herbs growing close to the winter wheat field it was often lower than 1. Values of nickel accumulation coefficient higher than the limits were found in Cichorium intybus L., Polygonum persicaria and Plantago lanceolata L.. Those results show that monitoring of herb plants growing around agricultural fields is necessary if they are to be used in medicine.

\section{Conclusion}

Such factors as the species and the distance from the field significantly affected cadmium and lead concentration in the plants. In the case of nickel there was a significant relationship between its concentration and the plant species only. 
Comparing cadmium, lead and nickel concentration in the biomass of six herb species it can be said that in the plants sampled close to the winter wheat field lead concentration exceeded the limits in all plants, apart from Cichorium intybus L. For the rest of metals the concentration in herb plants was below the limits for dry herbs.

Herbs sampled around the winter wheat field had a higher concentration of heavy metals than those sampled around the grain maize field. In herbs sampled one meter from each field cadmium concentration was significantly higher while for nickel the concentration was higher in plants growing ten meters from the fields. Plants growing one meter from the winter wheat field had a higher concentration of lead than those growing further from the field. In herbs sampled ten meters from the maize field lead concentration was higher than in those growing at the distance of one meter.

The average cadmium, lead and nickel concentration in soil sampled close to each field was much lower than concentration of those metals in average, non-contaminated soil.

In the soil-plant system there was diversity in the vales of accumulation coefficient of heavy metals in plants. The highest value was for cadmium then for nickel and the lowest for lead.

Comparing the result it can be concluded that using agricultural chemicals in growing maize and wheat did not cause a considerable rise in cadmium and nickel concentration outside the fields. Therefore it can be assumed that the concertation of those metals did not exceed the limits in crops growing in the fields. However, lead concentration in plants growing close to the winter wheat field was over the limit. Because of that heavy metal concentration in herbs growing in the natural habitat should be monitored in detail, separately for different species because heavy metal accumulation is significantly related to plant species.

\section{REFERENCES}

[1] Alloway, B.J. (1990): Heavy metals in soils. - Blackie, John Wiley \& Sons Inc., London, Glasgow, New York, pp. 339.

[2] Arslan, H., Güleryüz, G., Leblebici, Z., Kırmızı, S., Aksoy, A. (2010): Verbascum bombyciferum Boiss. (Scrophulariaceae) as possible bio-indicator for the assessment of heavy metals in the environment of Bursa, Turkey. - Environmental Monitoring and Assessment 163: 105-113. doi: 10.1007/s10661-009-0820-1

[3] Barazani, O., Sathiyamoorthy, P., Manandhar, U., Vulkan, R., Golan-Goldhirsh, A. (2004): Heavy metal accumulation by Nicotiana gluaca Graham in a solid waste disposal site. - Chemosphere 54: 867-872.

[4] Başgel, S., Erdemoğlu, S.B. (2006): Determination of metal and trace elements in some medicinal herbs and their infusions consumed in Turkey. - Science of the Total Environment 359: 82-89.

[5] Błoniarz, J., Zaręba, S., Wójcik, P. (2008): Evaluation of nickel and chromium in herbs and infusions used for the treatment of cardiovascular. - Bromatologia and Toxicological Chemistry 41(3): 349-353. (in Polish)

[6] Deng, H., Ye, Z.H., Wong, M.H. (2004): Accumulation of lead, zinc, copper and cadmium by 12 wetland plants species thriving in metal-contaminated sites in China. Environmental Pollution 134: 29-40.

[7] Garcia-Rico, L., Leyva-Perez, J., Jara-Marini, M.E. (2007): Content and daily intake of copper, zinc, lead, cadmium and mercury from dietary supplements in Mexico. - Food and Chemical Toxicology 45: 1599-1605. 
[8] Jankowski, K., Ciepiela, G.A., Jankowska, J., Szulc, W., Kolczarek, R., Sosnowski, J., Wiśniewska-Kadżajan, B., Malinowska, E., Radzka, E., Czeluściński, W., Deska, J. (2015): Content of lead and cadmium in aboveground plant organs of grasses growing on the areas adjacent to route of big traffic. - Environmental Science and Pollution Research 22(2): 978-87. doi: 10.1007/s11356-014-3634-9.

[9] Kabata-Pendias, A. (2000): Biogeochemistry of zinc. Zinc the environment ecological and analytical problems. - Papers Scientific Committee „Humans and the Environment" PAN Warsaw 26: 17-24. (in Polish)

[10] Kabata-Pendias, A., Pendias, H. (1999): Biogeochemistry of trace elements. PWN, Warsaw pp 398. (in Polish)

[11] Kloke, A., Sauerbeck, D.R., Vetter, H. (1984): The contamination of plants and soils with heavy metals and the transport of metals in the terrestrial food chains. In: Nriagu J.O. (eds.), Changing metal cycles and human health. Springer Verlag, Berlin, Heidelberg, New York, Tokyo, 113-141.

[12] Luginina, E.A., Egoshina, T.L. (2013): The peculiarities of heavy metals accumulation by wild medicinal and fruit plants. Annals of Warsaw University of Life Sciences, Agriculture 61: 97-103.

[13] Malinowska, E., Jankowski, K., Sosnowski, J., Wiśniewska-Kadżajan, B. (2015): Pesticide residues in cereal crop grains in Poland in 2013. - Environmental Monitoring and Assessment 187: 329. doi: 10.1007/s10661-015-4566-7

[14] Plesničar, A., Zupančič, N. (2005): Heavy metal contamination of roadside soils along Lujbljana-Obrežje highway. - RMZ-Materials and Geoenvironment. 52(2): 403-418.

[15] Ražic, S., Đogo, S., Slavković, L. (2008): Investigation on bioavailability of some essential and toxic elements in medicinal herbs. - Journal of Natural Medicines 62: 340344.

[16] Regulation of the Minister of Health of 13 January 2003 on maximum levels of chemical and biological contaminants that may be present in food, food ingredients, allowed additional substances, substances that help the processing or on food. (Dz.U.Nr 37, poz. 326, zał. 1). (in Polish)

[17] Salahinejad, M., Aflaki, F. (2010): Toxic and essential mineral elements content of black tea leaves and their tea infusions consumed in Iran. - Biological Trace Elements Research 134: 109-117.

[18] Sembratowicz, I., Rusinek, E., Ognik, K., Truchliński, J. (2009): Concentrations of trace elements and heavy metals at selected medicinal plants harvested in two vegetation periods. - Herba Polonica 55(1): 22-28. (in Polish)

[19] StatSoft, Inc. 2011 STATISTICA (data analysis software system), version 10. www.statsoft.com

[20] Terelak, H., Motowicka-Terelak, T., Struczyńska, T., Pietruch, Cz. (2002): Trace elements $(\mathrm{Cd}, \mathrm{Cu}, \mathrm{Ni}, \mathrm{Pb}, \mathrm{Zn})$ in soils of the Polish agricultural land. Library Environmental Monitoring, Inspection of Environmental Protection, Warsaw, 69. (in Polish)

[21] Terelak, H., Piotrowska, M. (1998): The lead content in the soils of farmland Polish and selected provinces. Lead the environment ecological and analytical problems. - Papers Scientific Committee „Humans and the Environment" PAN Warsaw 21: 19-24.

[22] Ulewicz-Magulska, B., Baranowska, M., Wesołowski, M. (2009): Assessment of the content of copper, manganese, zinc and iron in herbs and leaves of medicinal plants. Bromatologia and Toxicological Chemistry 42: 815-821. (in Polish)

[23] Van Bohemen, H.D., Van de Laak, W.H.J. (2003): The influence of road infrastructure and traffic on soil, water, and air quality. - Environmental Management 31(1): 50-68. 
[24] Wesołowski, M., Radecka, I. (2003): Medicinal plants. Elemental composition, source of minerals for plants, indicators of environmental contamination by heavy metals. - Polish Pharmacy 59(20): 911-919. (in Polish)

[25] Wiechuła, D., Loska, K., Jonderko, W. (2012): Assessment of pollution nickel stinging nettle (Urtica dioica L.) from the Silesian region. - Bromatologia and Toxicological Chemistry 45: 20-25. (in Polish) 